\title{
Bone Morphogenic Protein Signaling Is a Major Determinant of Dentate Development
}

\author{
Youngshik Choe, ${ }^{1}$ Anastasiia Kozlova, ${ }^{5}$ Daniel Graf, ${ }^{5}$ and Samuel J. Pleasure ${ }^{1,2,3,4}$ \\ ${ }^{1}$ Department of Neurology, Programs in ${ }^{2}$ Neuroscience and ${ }^{3}$ Developmental Stem Cell Biology, ${ }^{4}$ Eli and Edythe Broad Center of Regeneration Medicine and \\ Stem Cell Research, University of California, San Francisco, San Francisco, California 94158, and ${ }^{5}$ Institute of Oral Biology, Section of Orofacial \\ Development and Regeneration, ZZM, Faculty of Medicine, University of Zurich, 8006 Zurich, Switzerland
}

To understand life-long neurogenesis in the dentate gyrus (DG), characterizing dentate neural stem cells and the signals controlling their development are crucial. In the present study, we show that bone morphogenic protein (Bmp) signaling is a critical regulator of embryonic dentate development, required for initiating neurogenesis in embryonic DG progenitors and required for the establishment of dentate neural stem cells postnatally. We tested the hypothesis that Bmp signaling regulates dentate development in part by controlling the expression of Lef1, a Wnt responsive transcription factor expressed in dentate stem cells and absolutely required for dentate granule cell production. Bmp activation through the Acvr1 receptor induced Lef1 expression and neurogenesis in the embryonic DG. Ectopic expression of Bmp7 in the embryonic midline increased DG neurogenesis and inhibition of local Bmp signaling decreased embryonic DG neurogenesis. Mice with selective loss of Bmp expression due to defective meningeal development or with selective conditional deletion of meningeal Bmp7 also have dentate developmental defects. Conditional deletion of Activin receptor type I (Acvr1) or Smad4 (a downstream target nuclear effector of Bmp signaling) in DG neural stem cells resulted in defects in the postnatal subgranular zone and reduced neurogenesis. These results suggest that Acvr1-mediated meningeal Bmp signaling regulates Lef1 expression in the dentate, regulating embryonic DG neurogenesis, DG neural stem cell niche formation, and maintenance.

\section{Introduction}

The mammalian forebrain has two regions with active ongoing neurogenesis into adulthood: the subgranular zone (SGZ) in the dentate gyrus (DG), and the subventricular zone lining the lateral ventricles. In both sites the stem cell niche is established and maintained by a panoply of signals including Wnt, Sonic hedgehog (Shh), and bone morphogenic proteins (Bmps), which cooperate to maintain the neurogenic capacity of the niche (Galceran et al., 2000; Chenn and Walsh, 2002; Machold et al., 2003; Zhou et al., 2004; Lie et al., 2005; Machon et al., 2007; Favaro et al., 2009; Caronia et al., 2010; Mira et al., 2010; Munji et al., 2011). While many studies address the roles of individual morphogenic signaling pathways, these neural stem cell niches, illuminating the interplay of these signaling pathways is critical to understanding the physiologic and pathophysiologic regulation of new neuron production.

Previous studies showed that Wnt signaling is pivotal in the development of the embryonic DG and in postnatal DG stem cell niche signaling. Mice with mutations in critical components of the Wnt signaling pathway show defective DG development and

Received Jan. 10, 2013; revised Feb. 12, 2013; accepted Feb. 14, 2013.

Author contributions: Y.C. and S.J.P. designed research; Y.C. performed research; A.K. and D.G. contributed unpublished reagents/analytic tools; Y.C. and S.J.P. analyzed data; Y.C. and S.J.P. wrote the paper.

This work was supported by National Institutes of Health Grants DA017627 and MH077694, and the Glenn W. Johnson, Jr. memorial endowment.

Correspondence should be addressed to Samuel J. Pleasure, 675 Nelson Rising Lane, Room 214, University of California, San Francisco, San Francisco, CA 94158. E-mail: sam.pleasure@ucsf.edu.

DOI:10.1523/JNEUROSCI.0128-13.2013

Copyright $\odot 2013$ the authors $\quad 0270-6474 / 13 / 336766-10 \$ 15.00 / 0$ loss of DG neural stem cells (Galceran et al., 2000; Lee et al., 2000; Zhou et al., 2004; Li and Pleasure, 2005). In particular, Lef1, a Wnt-activated transcription factor selectively expressed in the developing dentate, is required for dentate granule neuron production (Galceran et al., 2000). Activation of the Wnt signaling pathway also directs the restricted expression of Proxl in DG granule neurons and regulates DG neurogenesis in the adult (Lie et al., 2005; Machon et al., 2007; Karalay et al., 2011). The role of Bmp signaling in dentate development is far less established, although there have been a few relevant publications. Conditional deletion of Smad4, a common transcriptional regulator for transforming growth factor $\beta$ ( $\operatorname{Tgf} \beta)$ signaling pathways, in the adult DG radial neural stem cells reduced dentate neurogenesis (Colak et al., 2008; Caronia et al., 2010) and compromised quiescence of adult dentate neural stem cells (Mira et al., 2010). In addition, a recent study showed that post-translational control of Noggin (Nog) expression is probably involved in DG neurogenesis as well (Guo et al., 2011). However, the role of Bmp signaling in establishing the dentate has been far less clear. The one study that explicitly examines this found only modest effects of loss of function for both Bmprla and 1b (Caronia et al., 2010). Thus, how Bmp signaling is integrated with other niche signals in regulating DG neurogenesis remains largely unexplored.

In the present study, we show that Lef1 is a landmark signaling molecule expressed by the DG neuronal stem cells throughout development of the DG and that activation of the Bmp signaling pathway through Activin receptor type I (Acvr1, also known as Alk2) regulates the expression of Lef1 in the DG stem cells at embryonic and postnatal stages. This study provides novel in- 

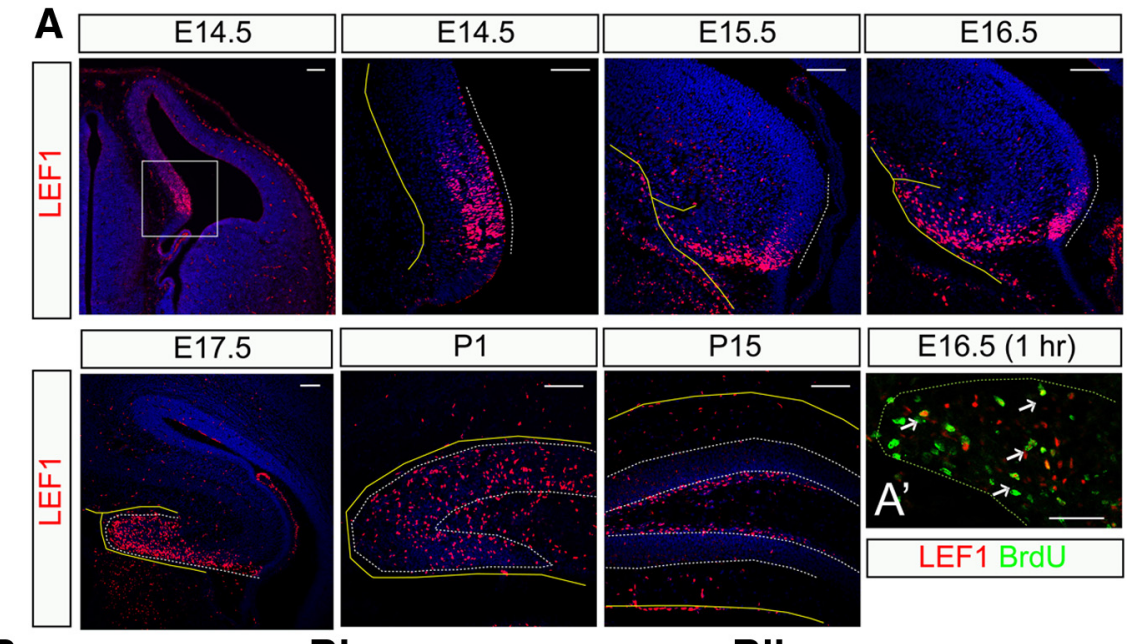

B
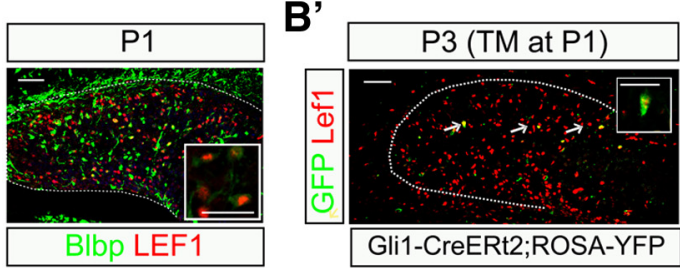

B'"

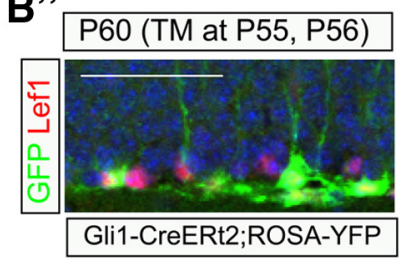

Figure 1. Expression of Lef1 during DG development. $A$, Lef1 expression was seen in the DG neural epithelium at E14.5 and in migrating cells toward the meninges (yellow lines) from E15.5 to E17.5. Lef1 + cells were observed in the granule cell layer and the hilus of the P1 DG and the P15 SGZ. Dashed lines in the top depict the dentate neural epithelial ventricular zone and dashed lines in the bottom outline the DG. $A^{\prime}$, Pregnant $C D 1$ mice were injected with $B r d U(50 \mathrm{mg} / \mathrm{kg})$ at $1 \mathrm{~h}$ before collection at E16.5. The DG was stained with Lef1 and BrdU to show the expression of Lef1 in the dividing cells. The dashed line outlines the DG and yellow lines mark the meninges covering the area of the $D G$. $\boldsymbol{B}$, The DG of P1 pups was stained with Lef1 and Blbp with higher power images in the inset. The dashed line outlines the DG. $\boldsymbol{B}^{\prime}$, Shh-responsive DG neural stem cells were marked in Gli1-CreERT2 mice. TM was injected at P1 and Cre recombined cells visualized with ROSA-YFP reporter mice at P3. Cells costained with GFP and Lef1 are indicated by arrows (inset). The dashed line outlines the DG. $\boldsymbol{B}^{\prime \prime}, \mathrm{TM}$ was given at P55, P56 of Gli1-CreERt2; ROSA-YFP animals and stained for GFP and Lef1 at P60. Scale bars: $100 \mu \mathrm{m}$; insets of $\boldsymbol{B}$ and $\boldsymbol{B}^{\prime}, 50 \mu \mathrm{m}$.

sight into how multiple signaling pathways regulating DG neurogenesis might cooperate.

\section{Materials and Methods}

Animals. Mice used in this study were previously described (Gli1CreERt2, Ahn and Joyner, 2004; hGFAP-Cre, Zhuo et al., 2001; Smad4 $4^{\text {lox }}$, Bardeesy et al., 2006; Acvr $1^{\text {lox }}$, Kaartinen and Nagy, 2001; Tgf $\beta$ r $2^{\text {lox }}$,Chytil et al., 2002; Pdgfr $\beta$-Cre, Foo et al., 2006; Foxc1 ${ }^{\text {lox }}$, Hayashi and Kume, 2008; Wnt1-Cre, Danielian et al., 1998; Bmp7 ${ }^{\text {lox }}$, Zouvelou et al., 2009) and ROSA-YFP Cre reporter mice were obtained from The Jackson Laboratory. Experimental mice were obtained by crossing male mice carrying an allele of a Cre recombinase and a heterozygous allele of floxed gene to female mice carrying homozygous floxed alleles. All mice were maintained in a mixed background and experimental mice were compared with littermate controls. The day of vaginal plug was considered to be embryonic day 0.5 (E0.5). Mouse colonies were housed at the University of California, San Francisco(UCSF), in accordance with UCSF Institutional Animal Care and Use Committee (IACUC) guidelines.

In utero electroporation. Timed pregnant CD1 mice were purchased from Charles River and the surgery was conducted according to IACUC approved protocols at UCSF. Briefly, the CD1 pregnant females were anesthetized with Nembutal. The uterine horns were exposed and embryos were injected with $1 \mu \mathrm{l}(1 \mathrm{mg} / \mathrm{ml})$ DNA in TE into the lateral ventricle. Electroporation was conducted at $33 \mathrm{~V}, 50 \mathrm{~ms}, 950 \mathrm{~ms}$ with five pulses. All DNA constructs were cloned into the pCIG2-IRES-EGFP vector from Dr. Franck Polleux by basic DNA cloning techniques. All template full-length cDNA was purchased from Open Biosystems. All experiments were repeated to get six electroporated embryos from more than four different electroporated mice. A constant active variant of
$\mathrm{E} 16.5(1 \mathrm{hr})$

Acvr1 (CA-Acvr1) and a kinase dead(KD) variant of Acvr1 (KD-Acvr1) depict Q207D (Macias-Silva et al., 1998) and K235R (Visser et al., 2001) point mutants respectively.

Tamoxifen and bromodeoxyuridine injection. Tamoxifen (TM; Sigma) stock was prepared by dissolving the powder in corn oil (Sigma) at 20 $\mathrm{mg} / \mathrm{ml}$. Neonates were single dosed subcutaneously with $2 \mathrm{mg}$ of TM and adult mice were dosed daily for $2 \mathrm{~d}$ with intraperitoneal injection of $4 \mathrm{mg}$ of TM/40 g per animal. Timed pregnant mice were subcutaneously injected with bromodeoxyuridine (BrdU) (Roche) dissolved in saline $(10 \mathrm{mg} / \mathrm{ml})$ at the dose of 50 $\mathrm{mg} / \mathrm{kg}$ animal.

Immunostaining and in situ hybridization. Embryos were collected at noon of embryonic days. Collected brains were fixed in $4 \%$ paraformaldehyde(PFA) in PBS overnight and cryoprotected in $20 \%$ sucrose/PBS for an additional day. OCT-embedded tissues were processed in a cryostat at $12 \mu \mathrm{m}$ sections for immunostaining and $20 \mu \mathrm{m}$ sections for in situ hybridization. Primary antibodies used for the immunostaining are chicken anti-GFP (Aves Labs; 1:1000), rabbit anti-Ki67 (LabVision; 1:200), rat anti-PECAM (Abcam; 1:1000), mouse anti-Reelin (Millipore; 1:1000), rabbit anti-pSMAD1/5/8 (Cell Signaling Technology; 1:100), rabbit anti-BLBP (Millipore Bioscience Research Reagents; 1:500), rabbit anti-GFAP (DAKO; 1:1000), rabbit anti-Tbr2 (Abcam; 1:200), rabbit anti-Prox1 (Bagri et al., 2002), and rabbit anti-LEF1 (Cell Signaling Technology; 1:200). Templates for RNA probes used for in situ hybridization were designed according to the Allen Developing Mouse Brain Atlas. All experiments were done by comparing control and mutant sections stained on the same slides to minimize variation in an experiment. For in situ hybridization, slides with $20 \mu \mathrm{m}$ sections were warmed to room temperature and treated with proteinase $\mathrm{K}(50 \mu \mathrm{g} / \mathrm{ml})$ for $1 \mathrm{~min}$, and fixed with $4 \%$ PFA for $10 \mathrm{~min}$. Acetylation was performed using $0.25 \%$ acetic anhydride in $0.1 \mathrm{~m}$ triethanolamine, $\mathrm{pH} 8.0$, for $10 \mathrm{~min}$, followed by three PBS washes. Slides were incubated with a hybridization buffer $(50 \%$ formamide, $5 \times$ SSC, $0.3 \mathrm{mg} / \mathrm{ml}$ yeast tRNA, $100 \mathrm{mg} / \mathrm{ml}$ heparin, $1 \times$ Denhardt's, $0.1 \%$ Tween 20, 0.1\% 3-[(3-cholamidopropyl) dimethylammonio]-1propane-sulfonate, $5 \mathrm{~mm}$ EDTA) for $10 \mathrm{~min}$ at $65^{\circ} \mathrm{C}$, followed by overnight incubation with digoxigenin(DIG)-labeled probes $(500 \mathrm{ng} / \mathrm{ml})$ in a hybridization buffer. Five high-stringency washes were performed with $0.2 \times \mathrm{SSC}$ at $65^{\circ} \mathrm{C}$. Slides were then incubated with alkaline phosphatase (AP)-conjugated anti-DIG antibodies (Roche) followed by the detection of signals with nitroblue tetrazolium/5-bromo-4-chloro-indolyl phosphate (Roche). Images were acquired at the Nikon Imaging Center at UCSF using an upright Nikon C1 spectral confocal microscope.

Statistics. For the pairwise analysis of samples we used Student's $t$ test of the SigmaPlot program (Systat Software). For multiple group comparison, we used one-way ANOVA with Tukey's multiple-comparison test using the GraphPad Prism5 program (Graphpad Software). Error bars indicate \pm SEM.

\section{Results}

Expression of Lef1 in DG stem cells across development

Lef1 mutant mice have a prominent dentate phenotype that goes along with the restricted expression of Lef1 mRNA within the developing forebrain to the dentate neuroepithelium and forming DG (Galceran et al., 2000; Zhou et al., 2004). We first set out to check the expression pattern of a Lef1 protein during the de- 
A

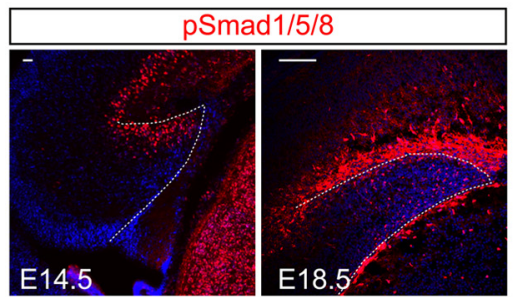

$\mathbf{A}^{\prime}$

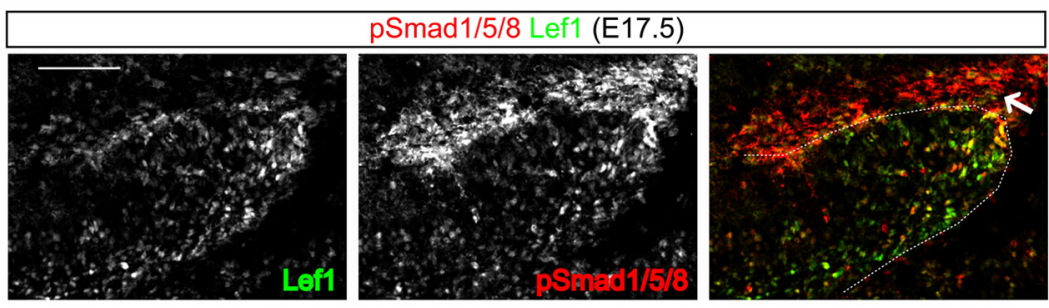

D

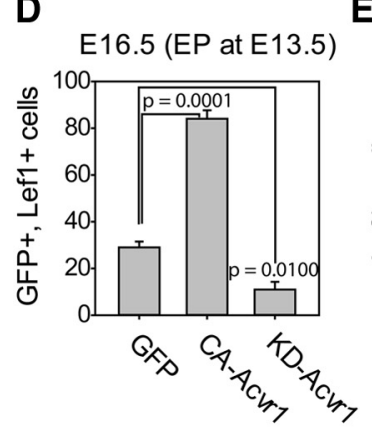

E

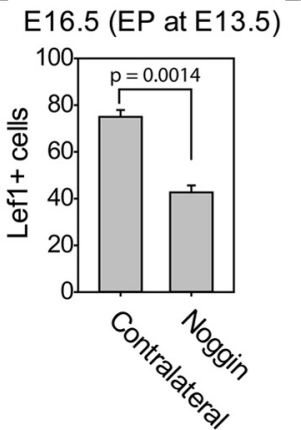

B

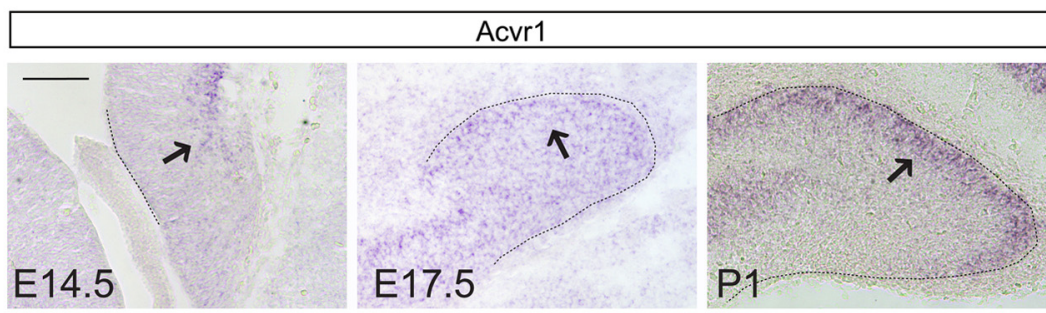

C

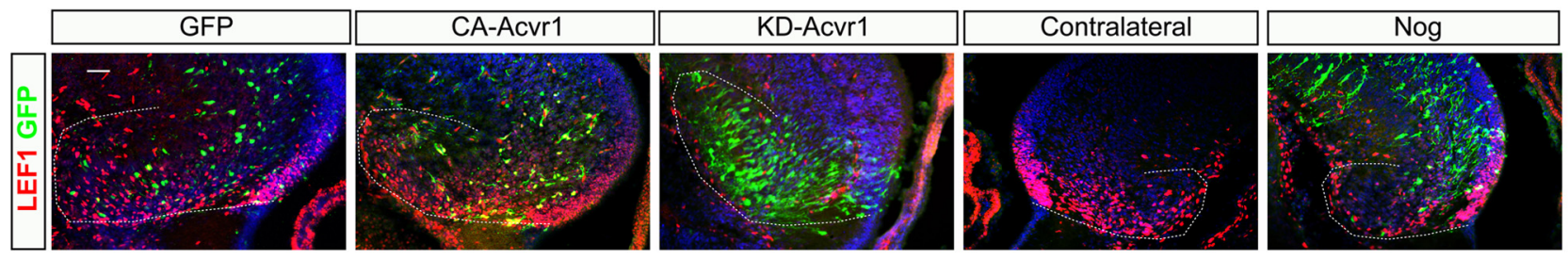

Figure 2. Bmp signaling in perinatal DG neural stem cells activates Lef1 expression. $A$, Expression of phospho-Smad1/5/8 in the DG at E14.5 and 18.5. Dashed lines outline the DG. $A^{\prime}$, Expression of phospho-Smad1/5/8 in the Lef1 + DG stem cells and the hippocampal fissure (arrow) at E17.5. Dashed lines outline the DG. $\boldsymbol{B}$, Expression of Acvr1 by in situ hybridization in the DG at E14.5, E17.5, and P1. Acvr1 is expressed in the DG migratory stream, the developing DG (arrow), and the CA3 region. C, Induction of Lef1 expression by activation of the Bmp signaling pathway through Acvr1 expression was examined by in utero electroporation. CA and KD variants of Acvr1 expression constructs were used to examine Acvr1-mediated Lef1 expression in the embryonic DG. GFPelectroporated DG was used as a control. Nog was used to show the effect of inhibiting the Bmp signaling pathway on Lef1 expression in the DG. The nonelectroporated contralateral DG was compared as a control group for Nog electroporation. Dashed lines outline the embryonic DG. $\boldsymbol{D}, \boldsymbol{E}$, The number of Lef1 + cells is presented from four independent experiments. Electroporation was conducted at E13.5 when the DG neural epithelium is exposed to the lateral ventricle and Lef1 expression was examined at E16.5 in the DG. Error bars indicate SEM. Scale bars, $100 \mu \mathrm{m}$.

velopment of DG stem cells using a recently available commercial antibody that is useful for immunohistologic analysis. Lef1 expression was detected in the dorsal midline at E14.5 and the expression of Lef1 in later developmental stages depicted the migration pattern of the presumptive DG stem cells (Altman and Bayer, 1990a,b; Li and Pleasure, 2005) (Fig. 1A). Lef1 expression was also seen in non-neural meningeal tissues and endothelial cells but was not seen in Cajal-Retzius cells within the dentate (data not shown). At P1, Lef1 was expressed in the forming dentate in the transient proliferative zone including the hilus and DG blades where there is abundant production of granule neurons. Expression of Lef1 at 2 weeks after birth correlated with the establishment of the SGZ stem niche and is essentially limited to this zone (Fig. 1A). To examine whether the cells expressing Lef1 were proliferative, we traced cells in S-phase with a single BrdU injection $1 \mathrm{~h}$ before analysis at E16.5. Cells colabeled for Lef1 and BrdU were seen in the DG migratory stream at E16.5 (Fig. $1 A^{\prime}$ ). At P1, Lef1 + cells were numerous and largely restricted to the dentate, some showing colabeling with Blbp (a marker of the glia-like dentate stem cells beginning to appear at this age) (Fig. $1 B)$. Although many of the Lef1 + cells were colabeled with Blbp and BrdU, we did not find examples of colabeling with Tbr2 (transit-amplifying cells) or Prox1 (DG granule neurons) (Fig. $1 B$; data not shown). Previous studies showed that around birth the DG stem cells also become Shh-responsive (Ahn and Joyner,
A
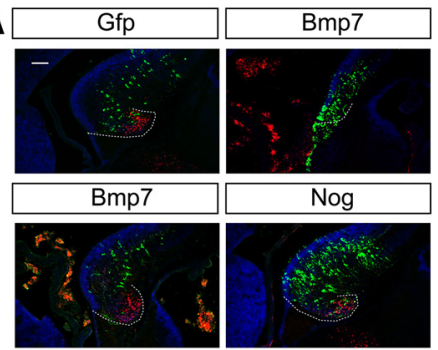

B

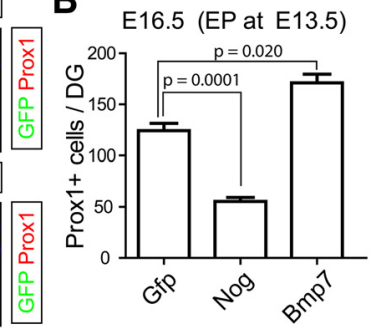

Figure 3. Bmp7 regulates embryonic DG neurogenesis. $\boldsymbol{A}$, Constructs as indicated were electroporated into the medial cortex at E13.5 and Prox1+ DG granule neurons were stained at E16.5. Dashed lines outline the embryonic DG. $\boldsymbol{B}$, The neurogenic effect of the signaling molecules was compared by counting Prox1-stained cells in the E16.5 DG from four independent experiments. The $p$ values from the Tukey's post hoc comparisons are presented after ANOVA. Error bars indicate SEM. Scale bars, $100 \mu \mathrm{m}$.

2005). We used Gli1-CreERt2 mice for short-term lineage tracing to label DG stem cells under the influence of the Shh signaling pathway by using ROSA-YFP reporter mice and introducing TM ( $2 \mathrm{mg} / \mathrm{pup}$ ) at P1 to Gli1-CreERt2 mice. This allowed us to identify Shh-responsive DG stem cells at P3 and we found that GFP+ cells were costained with Lef1 (Fig. $1 B^{\prime}$ ). Similarly, adult Shh-responsive DG stem cells expressed Lef1 and were predominantly radially oriented SGZ-based cells (Fig. 1 $B^{\prime \prime}$ ). 

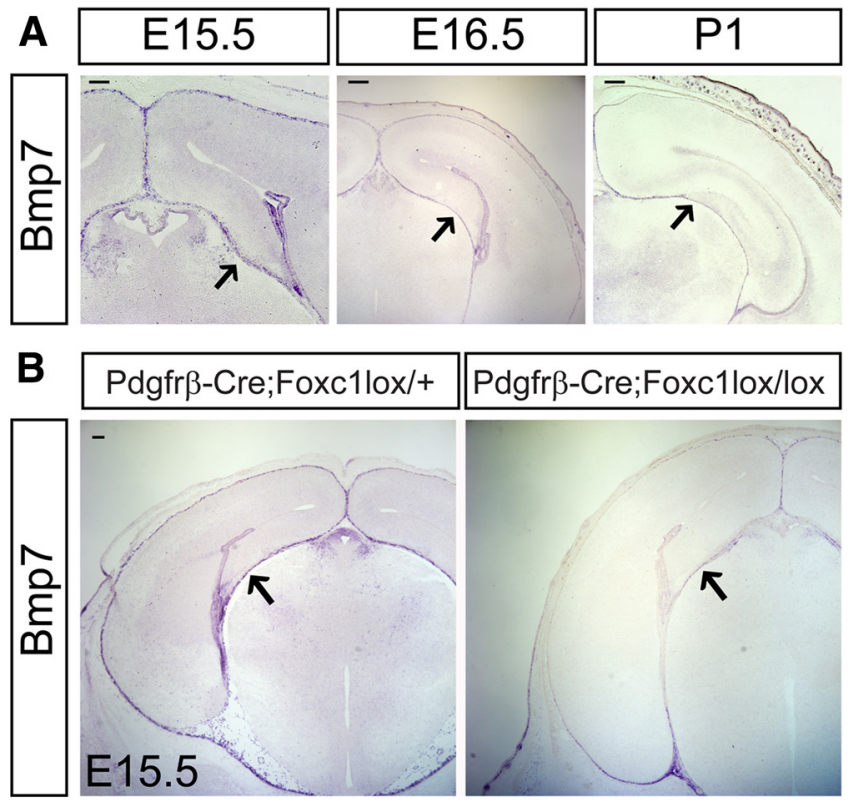

D

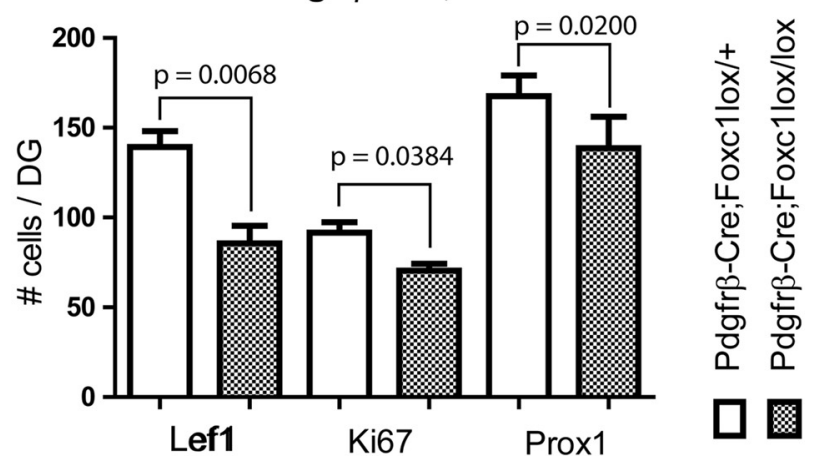

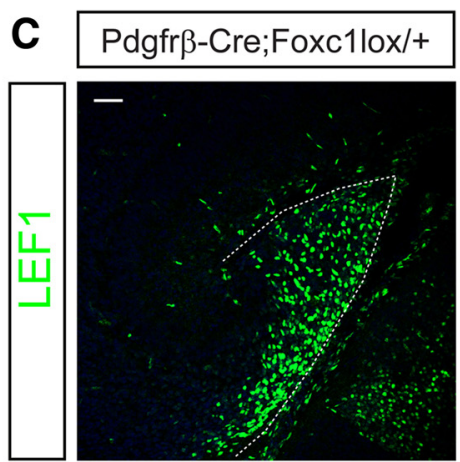
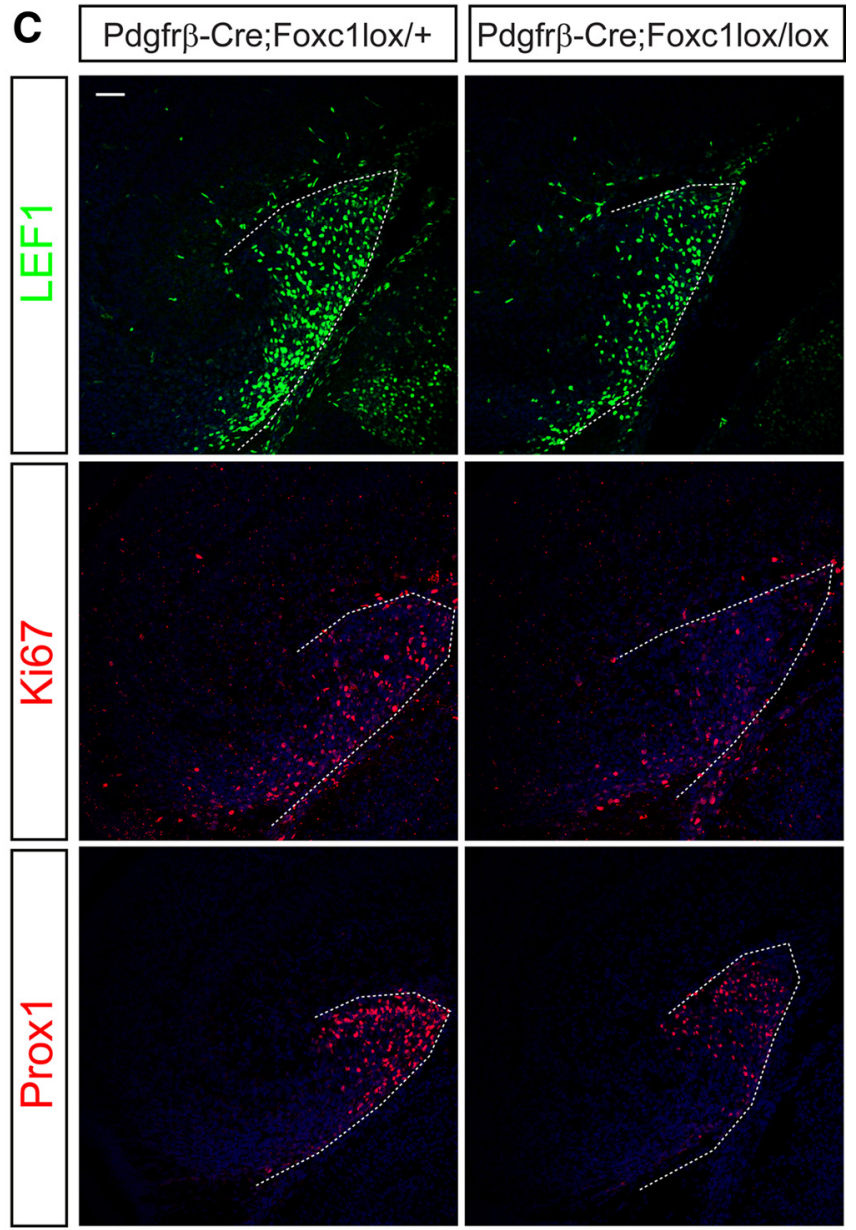

Figure 4. Decreased DG neurogenesis in mice with reduced meningeal Bmp expression. $\boldsymbol{A}$, Expression of Bmp7 at the level of the hippocampus was revealed by in situ hybridization using E15.5, E17.5 embryos and P1 pups. $\boldsymbol{B}$, Pdgfr $\beta$-Cre-mediated inhibition of meninges-specific Foxc1 expression (Pdgfr $\beta$-Cre; Foxc1 ${ }^{\text {lox/lox }}$ ) resulted in the decrease of Bmp7 expression in the meninges at E15.5 (arrows). C, Lef1, Ki67 (a marker for proliferating cells), and Prox1 immunostaining was examined in the E17.5 embryonic DG with DAPI counterstaining (blue). Dashed lines outline the embryonic DG. D, We counted the number of cells stained with Lef1, Ki67, and Prox1 in the DG. Four different litters were used for comparison. Error bars indicate SEM. Scale bars, $100 \mu \mathrm{m}$.

Thus, our data show that Lef1 is expressed in the cells in the dentate neuroepithelium and also in the dentate stem cells migrating to establish the ectopic proliferative zone where granule neurons are produced locally. Lef1 also continues to be expressed in radially oriented dentate progenitors through later postnatal ages as well (Choe and Pleasure, 2012). Thus, determining how Lef1 is expressed in such a restricted spatial domain in the developing medial pallium and dentate is of some interest since it should reveal important insights into how the dentate forms.

\section{Acvr1, a Bmp receptor, signaling regulates Lef1 expression in} the medial cortex

Previous studies showed that in other non-neural tissues Bmp signaling can induce Lef1 expression providing a potential mechanism whereby Bmp signaling can render receiving cells responsive to specific Wnt signaling (Kratochwil et al., 1996). Since Bmp ligands are expressed both by the developing meninges and the cortical hem (Choe et al., 2012; Segklia et al., 2012) it seemed quite possible that Bmps might play a role in inducing the expression of Lef1 specifically in the hem-adjacent neuroepithelium and then later in the dentate, which develops in close proximity to the meninges. To determine whether signaling is active in the early dentate, we stained for phospho-Smad1/5/8, which allows visualization of cells where Bmp signaling is active. Staining for phospho-Smad1/5/8 was detected in dentate cells close to the meninges at E14.5 and in the hilar germinal area at E18.5 as well as in many cells in the hippocampal fissure (Fig. 2A). To examine whether phospho-Smad1/5/8 is found in Lef1+ DG stem cells, we doublestained for phospho-Smad1/5/8 and Lef1 at E17.5. Lef1 + DG stem cells with evidence of Bmp signaling were readily seen in the hilus (Fig. $2 A^{\prime}$ ). Among type I Bmp receptors, Bmprla and Bmprlb were examined in previous studies but Acvr1 expression was not included in previous studies of DG development (Caronia et al., 2010). Previous studies of double mutant mice for Bmprla and $1 \mathrm{~b}$ showed that these mice have largely intact dentate development with fairly normal formation of the dentate SGZ, but it seemed clear that there should be some more potent effect of Bmp signaling in the dentate. Thus we wondered whether Acvr1 might be part of the missing picture of Bmp signaling in the dentate. Acvr1 is a serine/threonine transmembrane receptor related to Bmpr1a and $1 \mathrm{~b}$ that phosphorylates Smad1 and 5 relatively specifically after activation by Bmp7 (Macias-Silva et al., 1998), thus we examined expression of Acvr1 and found that Acvr1 is expressed at high levels in the hippocampus with highest 
levels of expression in the DG (arrow) and pyramidal regions of the developing hippocampus (Fig. 2B).

To examine the potential effects of Acvr1 signaling in the developing dentate, we tested whether Acvr1 directly regulates Lef1 expression. We electroporated a constitutively active (CA) variant of Acvr1 (Macias-Silva et al., 1998) into the developing DG and found that CA-Acvr1 cell autonomously induced expression of Lef1 in the DG ( $n=4$, Tukey's post hoc test, $p=0.001)$, while a KD variant of Acvr1 (Visser et al., 2001) blocked expression in GFP-expressing cells ( $n=4$, Tukey's post hoc test, $p=0.0100$ ). Importantly Nog dramatically reduced the expression of Lef1 ( $n=4, p=0.0014)$ in the entire expressing DG, thus indicating that endogenous Bmp signaling regulates Lef1 expression (Fig. $2 C-E$ ). These results indicate that activating Bmp signaling through Acvr1 robustly induces Lef1 expression in the embryonic DG and that Bmp signaling is an important regulator of Lef1 expression. Thus, we believe that $\mathrm{Bmp}$ signaling in the dentate is a key regulator of dentate development by regulating expression of Lef1, a component of Wnt signaling required for dentate formation.

\section{Bmp signaling regulates dentate granule neurogenesis in the embryonic DG}

Activation of the Bmp receptor Acvr1 regulates the expression of Lef1 in the developing dentate, but does Bmp signaling also regulate the production of dentate granule neurons? To address this we electroporated Bmp7 into the medial cortical wall at E13.5 and examined expression of Proxl, a marker for postmitotic granule cells at E16.5. We compared these effects to the effects of Nog, to inhibit endogenous Bmp signaling. Interestingly we found that high-level overexpression of Bmp7 induced loss of the DG, perhaps through the death of the DG neural epithelium and agenesis of the choroid plexus (see the cell debris in the ventricle) similar to that seen previously with high dosage Bmps in cortical cultures (Mabie et al., 1999), so we also examined animals with the low-level expression of Bmp7 and compared the number of Prox $1+$ cells with the DG electroporated with GFP or Nog. As shown in Fig 3, $A$ and $B$, lower level mis-expression of Bmp7 increased Prox1+ DG granule neurons and expression of Nog partially inhibited DG neurogenesis $(n=4, p=$ 0.001 (Nog), $p=0.020$ (Bmp7)). Thus, Bmp signaling does indeed regulate the production of Prox1+ dentate granule neurons along with the expression of the required Wnt signaling component Lef1.

\section{Bmp7-expressing meninges are important in regulating the late embryonic DG stem cell niche} Wnt expression persists throughout embryonic life in the cortical hem and its derivative, the fimbria, and activation of Wnt signaling induces DG neurogenesis and expression of Prox1 (Grove et al., 1998; Karalay et al., 2011). Wnts are expressed by the fimbria next to the DG, but what is the source of the Bmp ligands that might regulate DG development? We examined expression of Bmp ligands and SEM. Scale bars, $100 \mu \mathrm{m}$.

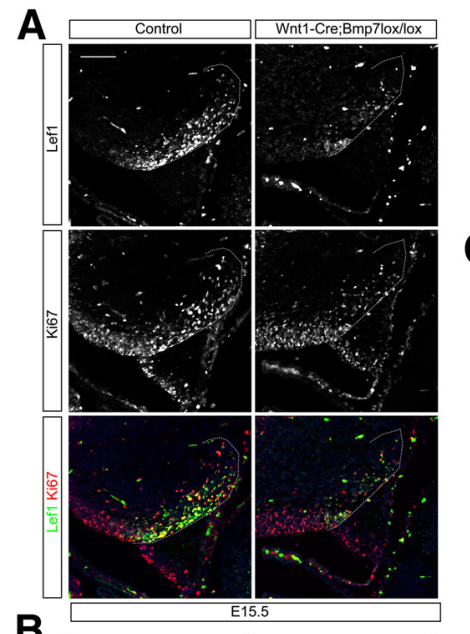

B

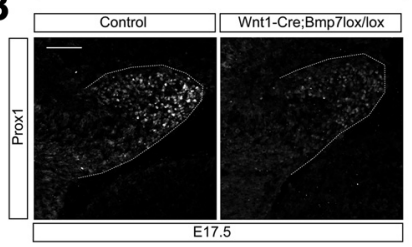

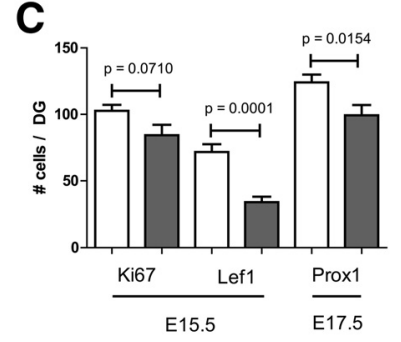

$\square$ Littermate control

Wnt1-Cre;Bmp7lox/lox
Figure 5. Loss of meningeal Bmp7 leads to inhibition of dentate neurogenesis. $A$, Lef1 and Ki67 immunostaining was conducted using the DG of Wnt1-Cre; Bmp7lox/lox mutants and littermate controls at E15.5. Dashed lines depict the DG. B, E17.5 embryos were used to stain dentate granule neurons using Prox1. Dashed lines depict the DG. C, Quantification of immunostained cells reveals significant decreases of Lef1 + dentate stem cells and Prox $1+$ dentate granule neurons at E15.5 and E17.5, respectively $(n=3)$. Error bars indicate SEM. Scale bars, $100 \mu \mathrm{m}$.

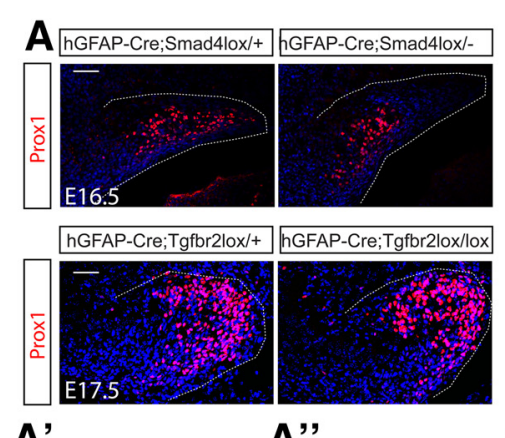

A' $\mathrm{E} 16.5(\operatorname{Smad} 4 \mathrm{fl})$

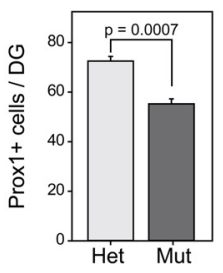

hGFAP-Cre;Smad4lox
$\mathbf{A}^{\prime \prime} \mathrm{E} 17.5(\mathrm{Tgf \beta r} r \mathrm{ffx})$

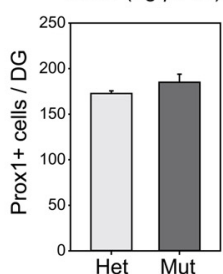

Het Mut

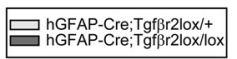

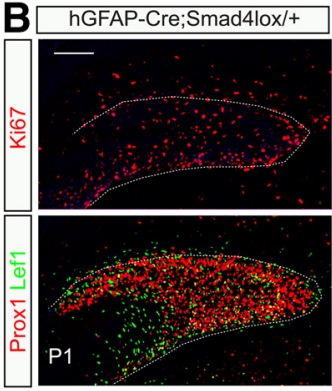

C

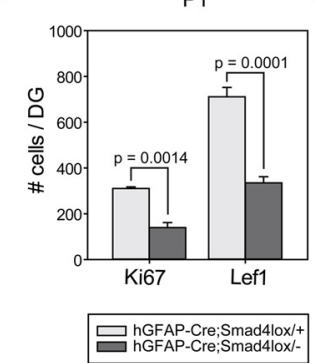
hGFAP-Cre;Smad4lox/-

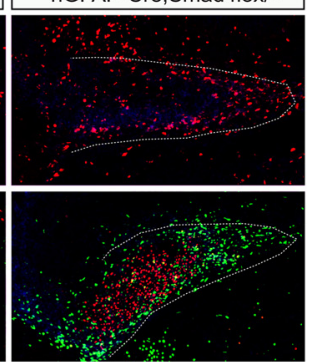

D

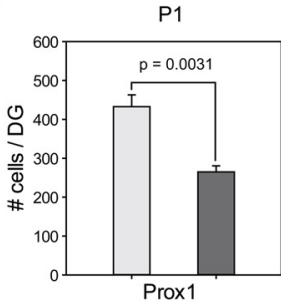

Prox

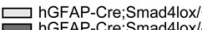

Figure 6. Failure of $D G$ neurogenesis by cell-autonomous inhibition of Bmp signaling in DG neural stem cells. $A$, Embryonic DG neurogenesis is decreased by loss of Smad4 expression in hGFAP-Cre lineage cells. The DG of embryos at E16.5 (Smad4) and E17.5

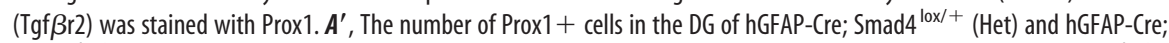
Smad4 ${ }^{\text {lox/- }}$ (Mut) embryos is presented $(n=4, p=0.0007)$. $A^{\prime \prime}$, The number of Prox $1+$ cells in the DG of hGFAP-Cre; Tgf $\beta r 2{ }^{\text {lox } /+}$ (Het) and hGFAP-Cre; Tgf $\beta$ r2 ${ }^{\text {lox/lox }}$ (Mut) embryos is presented ( $n=3$ ). B, hGFAP-Cre-mediated inhibition of Smad4 expression at P1 shows decreased neurogenesis along with decreased expression of Lef1 and Ki67. Dashed lines outline the DG. $\boldsymbol{C}, \boldsymbol{D}$, The number of Lef1, Ki67 ( $($ )-positive, and Prox1 (D)-positive cells was counted from P1 pups of four different litters $(n=4)$. Error bars indicate 

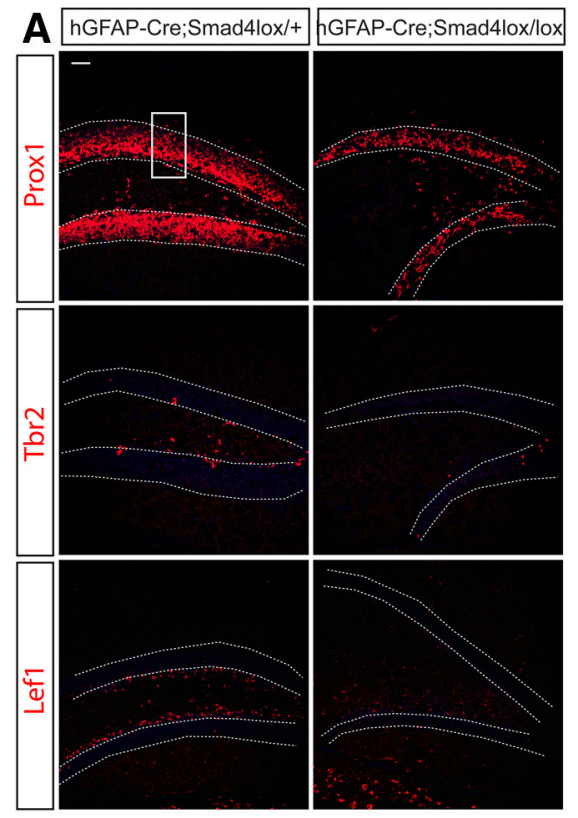

$$
\text { A' }
$$
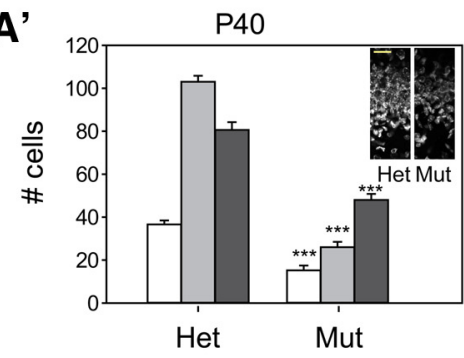

Tbr2+ cells/DG

$$
\begin{aligned}
& \square \text { Tbr2+ cells/DG } \\
& \square \text { Lef1+ cells/DG } \\
& \square \text { DAPI+ cells/200 } \mu \mathrm{m}
\end{aligned}
$$

Figure 7. Compromised postnatal neurogenesis by developmental inhibition of Bmp signaling. $\boldsymbol{A}, \mathrm{P} 40$ mice showed malformed SGZ neural stem cell niches and granule cell layers when the Bmp signaling pathway is inhibited in the DG stem cells from development onward. Effects of Smad4 inhibition in the hGFAP-Cre-expressing DG neural stem cells persisted to P40 as revealed with staining for Prox1, Tbr2, and Lef1. $\boldsymbol{A}^{\prime}$, The number of granule neurons (DAPI+ cells excluding the SGZ) as well as transitamplifying cells (Tbr2 + cells) were counted in control (Het, hGFAP-Smad4 ${ }^{\text {lox/+ }}$ ) and mutant animals (Mut, hGFAP-Smad4 ${ }^{\text {lox/lox }}$ ). Inset, DAPI-stained image of the boxed area of $\boldsymbol{A}\left(n=3,{ }^{* * *} p=0.0001\right)$. Number of granule cells are presented as number of cells in a $200 \mu \mathrm{m}$ box. $\boldsymbol{B}$, Inhibition of Tgf $\beta \mathrm{r} 2$ signaling pathway led to the slightly enlarged DG at P40 as shown with staining for Prox1, Tbr2, and Lef1. $\boldsymbol{B}^{\prime}$, The number of Tbr2 + cells, Lef1 + cells and granule cells (DAPI+) was counted from control (Het, hGFAP-Cre; $\operatorname{Tgf} \beta \mathrm{r}^{\text {lox/++}}$ ) and mutant animals (Mut, hGFAP-Cre; $\operatorname{Tgf} \beta \mathrm{r} 2^{\text {lox/lox }}$ ). Inset, DAPI-stained images of the boxed area of $\boldsymbol{B}(n=3, p=$ 0.0029). Dashed lines outline the $D G$ granule cell layer. Error bars indicate SEM. Scale bars: $\boldsymbol{A}, \boldsymbol{B}, 100 \mu \mathrm{m} ; \boldsymbol{A}^{\prime}, \boldsymbol{B}^{\prime}, 50 \mu \mathrm{m}$.

found that meningeal tissue is a major source of Bmp expression at the time of late embryonic DG neurogenesis. Considering that the migration route of DG progenitors is dependent on meningeally produced $\mathrm{Cxcl} 12$ and these cells spend time in a subpial transient stem cell niche ( $\mathrm{Li}$ et al., 2009), it is reasonable to hypothesize that Bmps from the meninges regulate dentate progenitor development and might drive Lef1 expression in DG stem cells. Staining of Bmp7 at the level of the DG from E15.5 to P1 showed strong expression in the meninges (Fig. 4A, arrows). We previously found that major defects in meningeal development from early in development result in major defects in the medial forebrain, making it hard to test dentate development specifically (Zarbalis et al., 2007). To assess later conditional loss of Bmps, we used the Pdgfr $\beta$-Cre to conditionally knock out Foxc1, a meningeal transcription factor, to decrease the expression of Bmp7 in the meninges covering the DG (Zarbalis et al., 2007; Siegenthaler et al., 2009; Choe et al., 2012). Pdgfr $\beta$ Cre; Foxc1 ${ }^{\text {lox/lox }}$ mutant mice showed decreased expression of Bmp7 in the meninges surrounding the DG (Fig. $4 B$, arrows); this persisted until E18.5 when the mutant embryos died (data not shown). We counted the number of Lef1, Ki67 (cells actively in the cell cycle), and Prox1 + DG granule neurons in the DG at E17.5. Pdgfr $\beta$-Cre; Foxc1 ${ }^{\text {lox/lox }}$ mutant embryos showed significant loss of Lef1, Ki67, and Proxl expression $(n=4, p=0.0068$ (Lef1), $p=0.0384$ (Ki67), $p=0.2000$ $($ Prox 1$)$ ) (Fig. 4C,D) supporting the idea that the meninges provide factors critical for the development of the embryonic DG and production of early DG neurons. These data are consistent with an important role for meningeal Bmps in this process. We wished to exclude a role for $\mathrm{Cxcl} 12$ in this phenotype since this chemokine is expressed by the meninges and also has some role in DG precursor behavior, so we examined the expression of $\mathrm{Cxcl} 12$ in $\mathrm{Pdgfr} \beta$-Cre; Foxc1 ${ }^{\text {lox/lox }}$ mutant embryos and found no significant change in expression (data not shown).

Neural crest-derived meningeal Bmp7 mediates embryonic DG neurogenesis Our data show that meningeal morphogens regulate dentate neurogenesis by regulating Lef1 expression in DG stem cells. To be certain that it is Bmp7 that is one of the main regulators of dentate Lef1 expression from the meninges, we used Wnt1-Cre to delete Bmp7 in neural crest-derived meningeal cells (Danielian et al., 1998; Zouvelou et al., 2009). At E15.5, Lef1 + cells are significantly $(p=0.0001)$ reduced in the mutant (Wnt1-Cre; Bmp $7^{\text {lox/lox }}$ ) and resulted in decreased production of DG granule neurons at E17.5 (Fig. 5A-C). This result supports our idea that meningeally produced Bmp7 is a component of the DG niche signal that controlling Lef1 expression in DG stem cells during development.

\section{Inhibition of embryonic Bmp signaling in DG stem cells impairs DG stem cell niche integrity}

Bmprla is known to regulate adult neural stem cell survival and we provided evidence that Acvr1 is involved in DG neurogenesis by regulating Lef1 expression in DG stem cells. Previous studies have also demonstrated a clear but modest role for Bmprla/1b signaling in the developing dentate (Caronia et al., 2010). Given our new data on Acvr1, we wanted to further address the role of the Bmp signaling pathway on DG stem cell niche formation by using hGFAP-Cre mice to target the developing dentate to ablate the expression of Smad4, a common transcription factor for both Bmp and $\operatorname{Tgf} \beta$ signaling. Tgf $\beta \mathrm{r} 2$ is the only $\operatorname{Tgf} \beta$ receptor that binds all Tgf $\beta$ isoforms and is required for activating the Smad4- 
dependent canonical Tgf $\beta$ signaling pathway (Wrana et al., 1992; Derynck and Zhang, 2003). To rule out the involvement of Tgf $\beta$ signaling pathway in dentate development, we compared Smad4 mutants to $\operatorname{Tgf} \beta \mathrm{r} 2$ conditional mice using the same Cre driver to selectively block the canonical $\operatorname{Tgf} \beta$ signaling pathway. Analysis of the hGFAP-Cre; Smad $4{ }^{\text {lox/- }}$ mutants at late embryonic development showed that by this stage, when the dentate is just becoming established, that there was a modest but significant loss of Prox $1+$ granule neurons $(n=4, p=0.0007)$ while the hGFAPCre; Tgf $\beta r 2^{\text {lox/lox }}$ mutants had no apparent phenotype (Fig. $\left.6 A, A^{\prime}, A^{\prime \prime}\right)$. Several days later, at $\mathrm{P} 1$, proliferating Ki67+ cells as well as Lef1 + cells were dramatically reduced in hGFAP-Cre; Smad $4{ }^{\text {lox/ }}$ mutants $(n=4, p=0.0014($ Ki67) $), p=0.0001$ (Lef1) $)$ (Fig. $6 B, C$ ). These reduced numbers of progenitor cells led to reduced neurogenesis as measured by staining for Prox1 at P1 $(n=4, p=0.0031)($ Fig. $6 B, D)$.

We examined animals at older ages to see the end results of the developmental defects in Bmp signaling using markers such as Lef1, Prox1, and Tbr2, a marker of the transit-amplifying cells in the SGZ (Hodge et al., 2008). There were dramatic defects in the number of granule neurons (Fig. 7A). There were also major losses of transit-amplifying cells (Tbr2+) and dentate stem cells $($ Lef1 +$)(n=3, p=0.0001)$ (Fig. $\left.7 A, A^{\prime}\right)$. In contrast, the Tgf $\beta \mathrm{r} 2$ conditional mutants showed slight thickening of the DG granule layer without significant difference of Tbr2 or Lef1 + cells as was expected from the previously reported inhibitory function of Tgf $\beta 1$ on adult neurogenesis $(n=3, p=0.0029$ (DAPI)) (Fig. $\left.7 B, B^{\prime}\right)$ (Buckwalter et al., 2006). These results suggest that late embryonic loss of Smad4 has major consequences for dentate development and the establishment of the dentate stem cell niche due in part to the loss of Bmp signaling during dentate formation.

\section{Acvr1 mediates DG neurogenesis and SGZ stem cell niche formation}

The dramatic effect of overall blockade of the Bmp signaling pathway on DG dentate development and ongoing neurogenesis is quite distinct from the published effects of loss of function of Bmprla/b (Caronia et al., 2010). This led us to wonder whether a key part of the signaling equation may be Acvrl. We wanted to examine whether loss of Acvr1 would have dramatic effects on DG progenitors and resulting DG neurogenesis as well as the maintenance of Lef1 + DG stem cells in vivo. We crossed hGFAPCre with Acvr1 conditional mice and examined the Lef1 and Prox1 expression at E16.5. As shown in Figure 8, $A$ and $A^{\prime}$, loss of Acvr1 in the hGFAP-Cre-expressing DG progenitors reduced both Lef1 and Prox 1 expression $[n=4, p=0.0001$ (Prox 1 ), $p=$ 0.0002 (Lef1)]; this strongly supports our in utero electroporation and conditional loss of the meningeal Bmp expression. We also examined whether loss of Acvrl at embryonic stages leads to disruption of dentate development and effects on the adult DG stem cell niche by examining Ki67, Lef1, Tbr2, and Prox1 at P15, $\mathrm{P} 30$, and $\mathrm{P} 40$. The numbers of cells expressing markers of proliferating cells (Lef1 and Ki67) were reduced in the mutant at P15 $(n=3, p=0.0001)$ (Fig. $\left.8 B, B^{\prime}\right)$. At both P30 and P40, we also observed decreases in Lef1 expression in the hGFAP-Cre; Acvr $1^{\text {lox } / \text { lox }}$ mutants $(n=4, p=0.0001)$. Tbr2 expressing transit amplifying cells were also reduced at $\mathrm{P} 30(n=4, p=0.0053)$ (Fig. $\left.9 A, A^{\prime}\right)$. The number of Ki67+ cells was low in the P30 hGFAPAcvrl ${ }^{\text {lox/lox }}$ mutant $(n=4, p=0.0515)$; however, similar at $\mathrm{P} 40$ $(n=4, p=0.8331)$, which might be due to increased gliogenesis associated with gliosis (Fig. $9 A, A^{\prime}, B, B^{\prime}$ ). To support this idea, we examined the expression of the dentate granule marker Prox1 and found a dramatic loss of Prox $1+$ cells in the hGFAP-Cre;
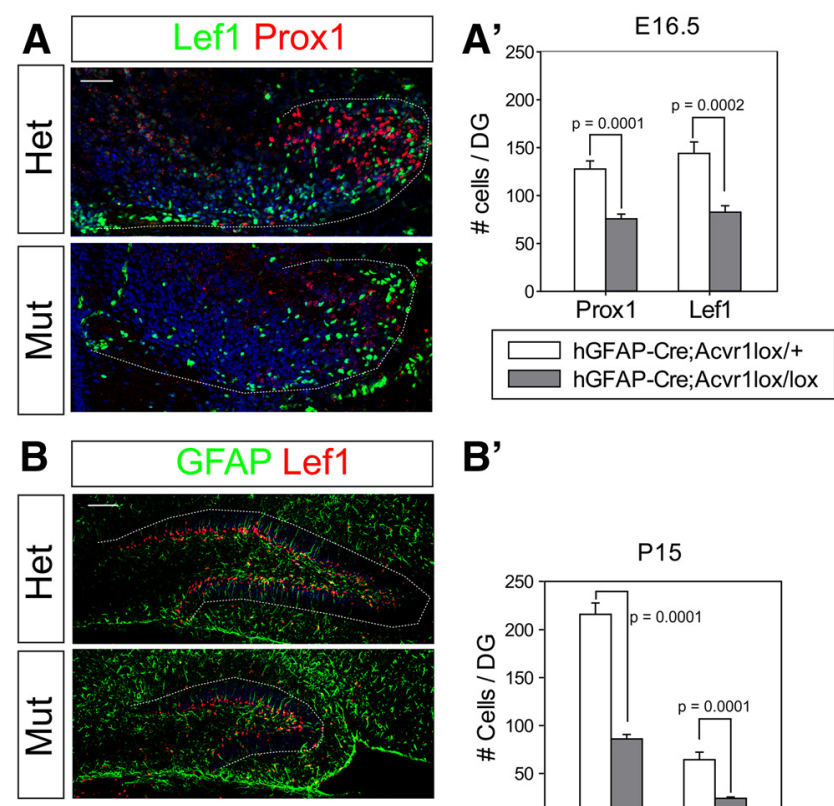

B'
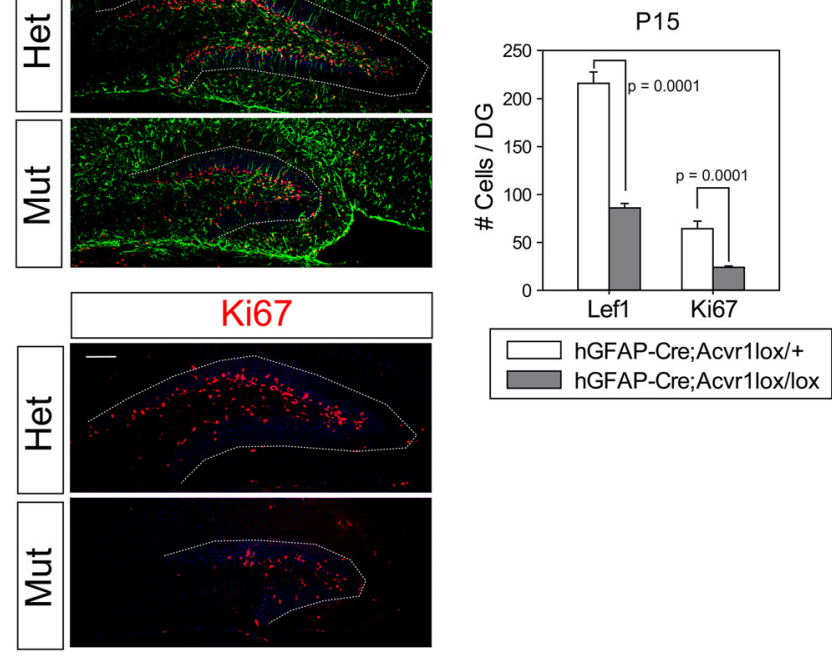

Figure 8. Loss of Acvr 1 from DG neural stem cells leads to defects in dentate development. $\boldsymbol{A}$, Lef1 and Prox1 immunostaining of the E16.5 embryonic DG from hGFAP-Cre; Acvr1 ${ }^{\text {lox/+ }}$ (Het) and hGFAP-Cre; Acvr1 ${ }^{\text {lox/lox }}$ (Mut). Dashed lines outline the DG. $\boldsymbol{A}^{\prime}$, The number of Lef1 or Prox1 + cells was counted from four control and mutant embryos obtained from three litters $(n=4)$. B, Lef1, GFAP, and Ki67 immunostaining of the DG obtained from hGFAP-Cre; Acvr $1^{\text {lox/+ }}$ and hGFAP-Cre; Acvr ${ }^{\text {lox/lox }}$ mice at P15. Dashed lines outline the DG. $\boldsymbol{B}^{\prime}$, Quantification of the immunostained cells from $\boldsymbol{B}(n=3)$. Error bars indicate SEM. Scale bars: $100 \mu \mathrm{m}$.

Acvr $1^{\text {lox/lox }}$ mutant at $\mathrm{P} 40$ (Fig. 9B). As expected by the decreased number of DG progenitors, the size of the DG was also reduced in the mutants (Figs. $8 B, 9 C$ ). Since the Lef1-expressing cells in the adult DG are mostly radial glial cells in the adult DG (Fig. $1 B^{\prime \prime}$ ), we also examined the number of Blbp - and GFAP-expressing radial glial DG neural stem cells. At both P30 and P40, the number of radial glial neural stem cells (we counted Blbp + cells as these are more easily identified) was significantly reduced in the mutant SGZ and GFAP + scaffolding cells were somewhat disorganized in hGFAP-Cre; Acvr $1^{\text {lox/lox }}$ mutant $(n=4, p=0.0018$ (P30), $p=$ 0.0001 (P40) for Blbp) (Fig. $\left.9 A^{\prime}, B^{\prime}, C, D\right)$.

\section{Discussion}

In this study we show that Bmp signaling strongly influences the development of the DG by regulating the formation of the dentate stem cell niche. Specifically we provide evidence that Bmp ligands from the meninges act through Acvrl to regulate the expression of Lef1 in the developing DG. These new findings provide an important framework for understanding the events that control the ability of the dentate to maintain long-term neurogenic capacity. In addition, our identification of a major role for the previously little studied Acvr1 receptor, a member of the Bmprl family, and identification of the meninges as a source of 

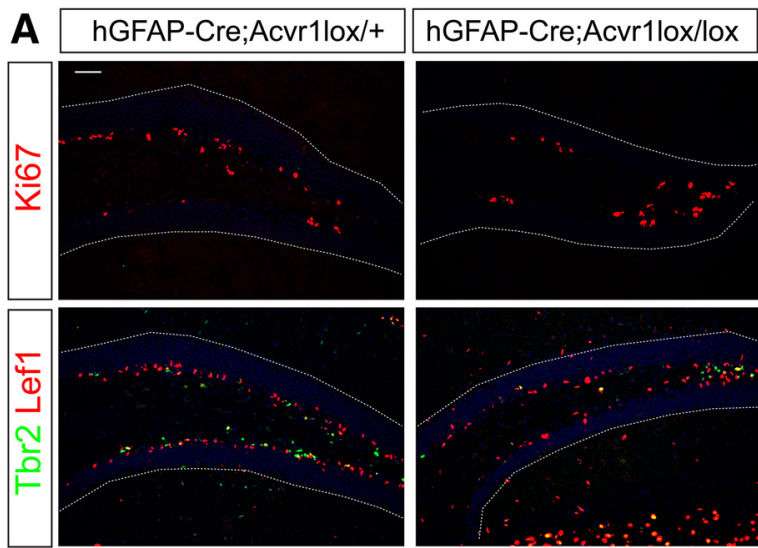

B'
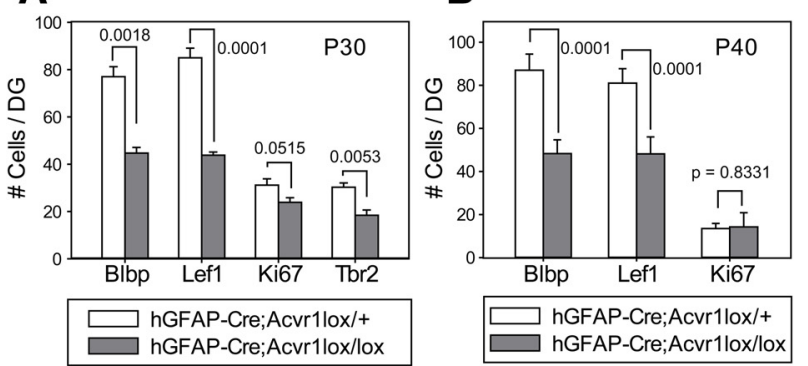
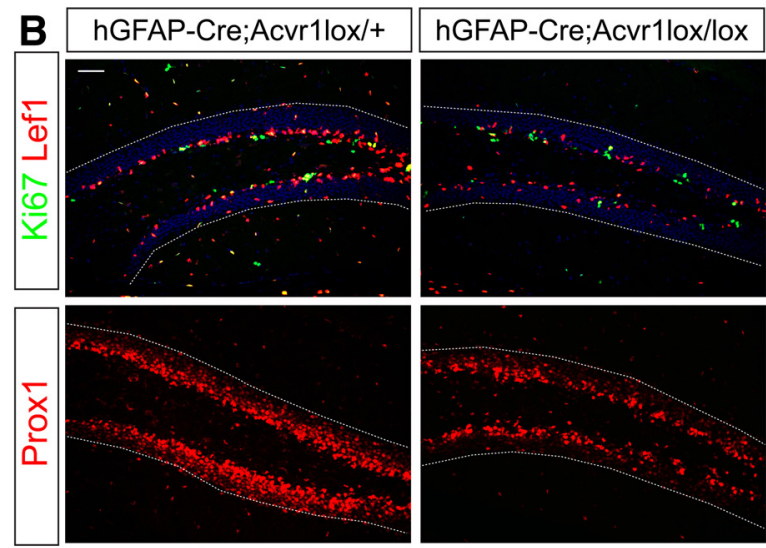

C
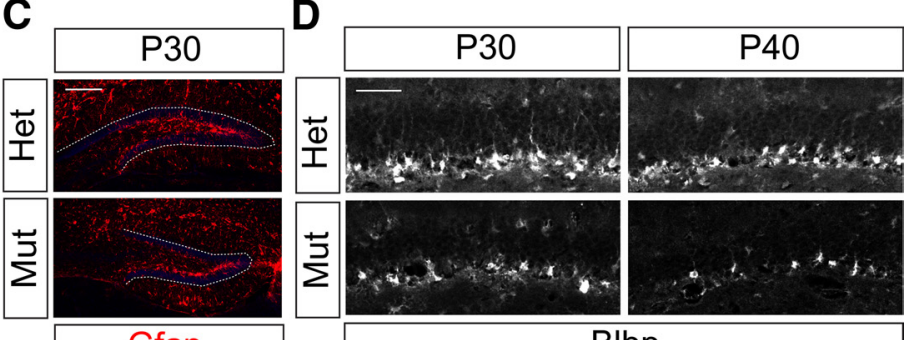

Blbp

Figure 9. Loss of Acvr1 leads to persistent defects in neurogenesis in the dentate stem cell niche. $A$, Ki67, Tbr2, and Lef1 immunostaining was conducted using the DG of hGFAP-Cre; Acvr1 lox/+ (Het) and hGFAP-Cre; Acvr $1^{\text {lox/lox }}$ (Mut) at P30. Dashed lines depict the DG. $\boldsymbol{A}^{\prime}$, Quantification of immunostained cells using four control and mutant animals from three litters ( $n=4$ ). $\boldsymbol{B}$, P40 animals were used to stain Ki67, Lef1, and Prox1. $\boldsymbol{B}^{\prime}$, Quantification of Blbp, Lef1, and Ki67+ cells at P40 using four control and mutant animals from three litters ( $n=4$ ). $\boldsymbol{C}, \boldsymbol{D}$, Immunostaining of GFAP using P30 (C) and staining of Blbp using P30 and P40 (D) animals $(n=4)$. Error bars indicate SEM. Scale bars: $100 \mu \mathrm{m}$.

Bmp7 are important developments revealing for the first time the central role of Bmp signaling in development of the dentate stem cell niche.

\section{Bmp signaling controls Wnt responsiveness in the developing dentate}

A number of studies over the last decade have made it very clear that Wnt signaling is particularly important in the regulation of dentate granule cell production during development and in postnatal life (Galceran et al., 2000; Zhou et al., 2004; Li and Pleasure, 2005; Lie et al., 2005). The function of Lef1, a Wnt-responsive transcription factor, is absolutely required for granule cell production (Galceran et al., 2000). Recent studies have also shown that Prox1, a transcription factor required for dentate granule cell fate, is directly regulated by Wnt signaling (Machon et al., 2007; Karalay et al., 2011). In this study we show that Lef1 is quite selectively expressed in the dentate progenitor lineage at a variety of stages. Since Lef1 plays a truly central role during dentate neurogenesis, factors that regulate the selective expression of Lef1 in the dentate lineage should be important regulators of dentate development and neurogenesis. One of the key regulators of Lef1 expression is Wnt signaling itself (Hovanes et al., 2001; Filali et al., 2002); this makes sense since the dentate forms in proximity to the cortical hem, the strongest source of Wnt ligands in the developing cortex (Grove et al., 1998).

A number of studies indicate that Wnt signaling alone is insufficient to generate the appropriate milieu for dentate development. A mixture of ligands from the cortical hem is apparently necessary and sufficient to induce ectopic dentate gyri in the cortex (Mangale et al., 2008). Also, previous studies showed that Bmps produced by the cortical hem are required at early times to allow formation of the hippocampus as a whole (Monuki et al., 2001). This work suggested to us a potential role for Bmp ligands as an additional regulator of dentate development at later stages, when the dentate is established. Since Bmp ligands can induce Lef1 expression in non-neural tissues we formed the hypothesis that Bmps from the hem and later from the meninges regulate the expression of Lef1. Our results showing that activating and blocking the Bmp signaling pathway selectively in the dentate regulates the number of Lef1-expressing cells are clearly consistent with this hypothesis. We believe this provides an important new advance in our understanding of the selective mechanisms governing dentate development and neurogenesis.

\section{The distinct role of Acvr1 in dentate development}

The developmental ablation of type I Bmp receptors, Bmpr la and $1 b$, results in defective DG formation partially through the inhibition of Wnt signaling molecules from the cortical hem and not solely through cell-autonomous inhibition of Bmp signal transduction in the DG (Caronia et al., 2010). The specification of the choroid plexus, the most dorsomedial derivative, is also dependent on the Bmprla signaling pathway (Hébert et al., 2002), which imposes difficulties in interpreting results from inhibiting Bmp receptor signaling in a nontissue-specific manner. Acvr1, however, is not expressed in the cortical hem, unlike Bmprla (Caronia et al., 2010). This implied to us that this additional member of the Bmpr1 family potentially has a specific role inducing Lef1 expression. This idea is amply supported by our results showing cell-autonomous regulation of Lef1 expression by Acvr1 in electroporation experiments and in conditional mutant mice. It is possible that there is some compensation by other Bmpr1 family members that tends to 
limit the severity of the Acvr1 phenotype, however, it is abundantly clear that this receptor has a key role in dentate development and probably ongoing neurogenesis.

\section{Roles of the meninges in dentate development}

What is the source of Bmp ligands regulating dentate development? Almost certainly at early stages Bmps are made by the hem and are also available from the CSF (made by the choroid plexus) and are important for patterning the medial cortical wall and future hippocampus (Furuta et al., 1997; Segklia et al., 2012). It is likely that these sources are also responsible in part, along with Wnt signaling, for the distribution of Lef1 in the medial wall before the dentate is formed. Once dentate development commences, Lef1-expressing cells are seen relocating to the developing dentate field, away from the ventricular lumen, where they expand dramatically and then ultimately settle in the SGZ to become dentate stem cells. We showed quite clearly that ectopic Bmp7 and Bmp inhibitors expressed in the forming dentate regulate the number of Lef1+ cells as well as the production of Prox $1+$ granule neurons. This suggests that a local source of Bmp7 might be important in the developing dentate, and indeed, we found that mice with mutations causing loss of meningeal Bmp7 expression have reduced numbers of Lef $1+$ cells and impaired dentate neurogenesis. Thus, Bmp7 produced by the meninges is likely to be a key regulator of dentate development, and given the continued postnatal phenotype seen in the Acvrl and Smad4 mutant mice, it is possible that production of Bmp7 by the meninges has a continuing role in postnatal neurogenesis. This is quite consistent with previous studies showing roles of Bmp signaling in adult neurogenesis, although these studies never considered the relevant physiologic sources of Bmp ligands in the adult dentate (Bonaguidi et al., 2008; Caronia et al., 2010; Mira et al., 2010).

In summary, we provide clear evidence that Bmp signaling, via the lesser-studied Acvrl receptor, is a key player in the development of the DG and the establishment of the dentate stem cell niche. Our results show that this is likely to be related to the control of Wnt responsiveness in the dentate niche as controlled by the expression of the key Wnt responsive transcription factor Lef1. This work helps to establish the development of the dentate as a process critically regulated by the intersection of a number of fundamental developmental signaling pathways.

\section{References}

Ahn S, Joyner AL (2004) Dynamic changes in the response of cells to positive hedgehog signaling during mouse limb patterning. Cell 118:505-516. CrossRef Medline

Ahn S, Joyner AL (2005) In vivo analysis of quiescent adult neural stem cells responding to Sonic hedgehog. Nature 437:894-897. CrossRef Medline

Altman J, Bayer SA (1990a) Mosaic organization of the hippocampal neuroepithelium and the multiple germinal sources of dentate granule cells. J Comp Neurol 301:325-342. CrossRef Medline

Altman J, Bayer SA (1990b) Migration and distribution of two populations of hippocampal granule cell precursors during the perinatal and postnatal periods. J Comp Neurol 301:365-381. CrossRef Medline

Bagri A, Gurney T, He X, Zou YR, Littman DR, Tessier-Lavigne M, Pleasure SJ (2002) The chemokine SDF1 regulates migration of dentate granule cells. Development 129:4249-4260. Medline

Bardeesy N, Cheng KH, Berger JH, Chu GC, Pahler J, Olson P, Hezel AF, Horner J, Lauwers GY, Hanahan D, DePinho RA (2006) Smad4 is dispensable for normal pancreas development yet critical in progression and tumor biology of pancreas cancer. Genes Dev 20:3130-3146. CrossRef Medline

Bonaguidi MA, Peng CY, McGuire T, Falciglia G, Gobeske KT, Czeisler C, Kessler JA (2008) Noggin expands neural stem cells in the adult hippocampus. J Neurosci 28:9194-9204. CrossRef Medline
Buckwalter MS, Yamane M, Coleman BS, Ormerod BK, Chin JT, Palmer T, Wyss-Coray T (2006) Chronically increased transforming growth factor-betal strongly inhibits hippocampal neurogenesis in aged mice. Am J Pathol 169:154-164. CrossRef Medline

Caronia G, Wilcoxon J, Feldman P, Grove EA (2010) Bone morphogenetic protein signaling in the developing telencephalon controls formation of the hippocampal dentate gyrus and modifies fear-related behavior. J Neurosci 30:6291-6301. CrossRef Medline

Chenn A, Walsh CA (2002) Regulation of cerebral cortical size by control of cell cycle exit in neural precursors. Science 297:365-369. CrossRef Medline

Choe Y, Pleasure SJ (2012) Wnt signaling regulates intermediate precursor production in the postnatal dentate gyrus by regulating Cxcr4 expression. Dev Neurosci 34:502-514. CrossRef

Choe Y, Siegenthaler JA, Pleasure SJ (2012) A cascade of morphogenic signaling initiated by the meninges controls corpus callosum formation. Neuron 73:698-712. CrossRef Medline

Chytil A, Magnuson MA, Wright CV, Moses HL (2002) Conditional inactivation of the TGF-beta type II receptor using Cre:Lox. Genesis 32:73-75. CrossRef Medline

Colak D, Mori T, Brill MS, Pfeifer A, Falk S, Deng C, Monteiro R, Mummery C, Sommer L, Götz M (2008) Adult neurogenesis requires Smad4mediated bone morphogenic protein signaling in stem cells. J Neurosci 28:434-446. CrossRef Medline

Danielian PS, Muccino D, Rowitch DH, Michael SK, McMahon AP (1998) Modification of gene activity in mouse embryos in utero by a tamoxifeninducible form of Cre recombinase. Curr Biol 8:1323-1326. CrossRef Medline

Derynck R, Zhang YE (2003) Smad-dependent and Smad-independent pathways in TGF-beta family signalling. Nature 425:577-584. CrossRef Medline

Favaro R, Valotta M, Ferri AL, Latorre E, Mariani J, Giachino C, Lancini C, Tosetti V, Ottolenghi S, Taylor V, Nicolis SK (2009) Hippocampal development and neural stem cell maintenance require Sox2-dependent regulation of Shh. Nat Neurosci 12:1248-1256. CrossRef Medline

Filali M, Cheng N, Abbott D, Leontiev V, Engelhardt JF (2002) Wnt-3A/ beta-catenin signaling induces transcription from the LEF-1 promoter. J Biol Chem 277:33398-33410. CrossRef Medline

Foo SS, Turner CJ, Adams S, Compagni A, Aubyn D, Kogata N, Lindblom P, Shani M, Zicha D, Adams RH (2006) Ephrin-B2 controls cell motility and adhesion during blood-vessel-wall assembly. Cell 124:161-173. CrossRef Medline

Furuta Y, Piston DW, Hogan BL (1997) Bone morphogenetic proteins (BMPs) as regulators of dorsal forebrain development. Development 124: 2203-2212. Medline

Galceran J, Miyashita-Lin EM, Devaney E, Rubenstein JL, Grosschedl R (2000) Hippocampus development and generation of dentate gyrus granule cells is regulated by LEF1. Development 127:469-482. Medline

Grove EA, Tole S, Limon J, Yip L, Ragsdale CW (1998) The hem of the embryonic cerebral cortex is defined by the expression of multiple Wnt genes and is compromised in Gli3-deficient mice. Development 125: 2315-2325. Medline

Guo W, Zhang L, Christopher DM, Teng ZQ, Fausett SR, Liu C, George OL, Klingensmith J, Jin P, Zhao X (2011) RNA-binding protein FXR2 regulates adult hippocampal neurogenesis by reducing Noggin expression. Neuron 70:924-938. CrossRef Medline

Hayashi H, Kume T (2008) Forkhead transcription factors regulate expression of the chemokine receptor CXCR4 in endothelial cells and CXCL12induced cell migration. Biochem Biophys Res Commun 367:584-589. CrossRef Medline

Hébert JM, Mishina Y, McConnell SK (2002) BMP signaling is required locally to pattern the dorsal telencephalic midline. Neuron 35:1029-1041. CrossRef Medline

Hodge RD, Kowalczyk TD, Wolf SA, Encinas JM, Rippey C, Enikolopov G, Kempermann G, Hevner RF (2008) Intermediate progenitors in adult hippocampal neurogenesis: Tbr2 expression and coordinate regulation of neuronal output. J Neurosci 28:3707-3717. CrossRef Medline

Hovanes K, Li TW, Munguia JE, Truong T, Milovanovic T, Lawrence Marsh J, Holcombe RF, Waterman ML (2001) Beta-catenin-sensitive isoforms of lymphoid enhancer factor-1 are selectively expressed in colon cancer. Nat Genet 28:53-57. CrossRef Medline

Kaartinen V, Nagy A (2001) Removal of the floxed neo gene from a condi- 
tional knockout allele by the adenoviral Cre recombinase in vivo. Genesis 31:126-129. CrossRef Medline

Karalay O, Doberauer K, Vadodaria KC, Knobloch M, Berti L, Miquelajauregui A, Schwark M, Jagasia R, Taketo MM, Tarabykin V, Lie DC, Jessberger S (2011) Prospero-related homeobox 1 gene (Prox1) is regulated by canonical Wnt signaling and has a stage-specific role in adult hippocampal neurogenesis. Proc Natl Acad Sci USA 108:5807-5812. CrossRef Medline

Kratochwil K, Dull M, Farinas I, Galceran J, Grosschedl R (1996) Lef1 expression is activated by BMP-4 and regulates inductive tissue interactions in tooth and hair development. Genes Dev 10:1382-1394. CrossRef Medline

Lee SM, Tole S, Grove E, McMahon AP (2000) A local Wnt-3a signal is required for development of the mammalian hippocampus. Development 127:457-467. Medline

Li G, Pleasure SJ (2005) Morphogenesis of the dentate gyrus: what we are learning from mouse mutants. Dev Neurosci 27:93-99. CrossRef Medline

Li G, Kataoka H, Coughlin SR, Pleasure SJ (2009) Identification of a transient subpial neurogenic zone in the developing dentate gyrus and its regulation by Cxcl12 and reelin signaling. Development 136:327-335. CrossRef Medline

Lie DC, Colamarino SA, Song HJ, Désiré L, Mira H, Consiglio A, Lein ES, Jessberger S, Lansford H, Dearie AR, Gage FH (2005) Wnt signalling regulates adult hippocampal neurogenesis. Nature 437:1370-1375. CrossRef Medline

Mabie PC, Mehler MF, Kessler JA (1999) Multiple roles of bone morphogenetic protein signaling in the regulation of cortical cell number and phenotype. J Neurosci 19:7077-7088. Medline

Machold R, Hayashi S, Rutlin M, Muzumdar MD, Nery S, Corbin JG, GritliLinde A, Dellovade T, Porter JA, Rubin LL, Dudek H, McMahon AP, Fishell G (2003) Sonic hedgehog is required for progenitor cell maintenance in telencephalic stem cell niches. Neuron 39:937-950. CrossRef Medline

Machon O, Backman M, Machonova O, Kozmik Z, Vacik T, Andersen L, Krauss S (2007) A dynamic gradient of Wnt signaling controls initiation of neurogenesis in the mammalian cortex and cellular specification in the hippocampus. Dev Biol 311:223-237. CrossRef Medline

Macías-Silva M, Hoodless PA, Tang SJ, Buchwald M, Wrana JL (1998) Specific activation of Smad1 signaling pathways by the BMP7 type I receptor, ALK2. J Biol Chem 273:25628-25636. CrossRef Medline

Mangale VS, Hirokawa KE, Satyaki PR, Gokulchandran N, Chikbire S, Subramanian L, Shetty AS, Martynoga B, Paul J, Mai MV, Li Y, Flanagan LA, Tole S, Monuki ES (2008) Lhx2 selector activity specifies cortical iden- tity and suppresses hippocampal organizer fate. Science 319:304-309. CrossRef Medline

Mira H, Andreu Z, Suh H, Lie DC, Jessberger S, Consiglio A, San Emeterio J, Hortigüela R, Marqués-Torrejón MA, Nakashima K, Colak D, Götz M, Fariñas I, Gage FH (2010) Signaling through BMPR-IA regulates quiescence and long-term activity of neural stem cells in the adult hippocampus. Cell Stem Cell 7:78-89. CrossRef Medline

Monuki ES, Porter FD, Walsh CA (2001) Patterning of the dorsal telencephalon and cerebral cortex by a roof plate-Lhx2 pathway. Neuron 32:591604. CrossRef Medline

Munji RN, Choe Y, Li G, Siegenthaler JA, Pleasure SJ (2011) Wnt signaling regulates neuronal differentiation of cortical intermediate progenitors. J Neurosci 31:1676-1687. CrossRef Medline

Segklia A, Seuntjens E, Elkouris M, Tsalavos S, Stappers E, Mitsiadis TA, Huylebroeck D, Remboutsika E, Graf D (2012) Bmp7 regulates the survival, proliferation, and neurogenic properties of neural progenitor cells during corticogenesis in the mouse. PLoS One 7:e34088. CrossRef Medline

Siegenthaler JA, Ashique AM, Zarbalis K, Patterson KP, Hecht JH, Kane MA, Folias AE, Choe Y, May SR, Kume T, Napoli JL, Peterson AS, Pleasure SJ (2009) Retinoic acid from the meninges regulates cortical neuron generation. Cell 139:597-609. CrossRef Medline

Visser JA, Olaso R, Verhoef-Post M, Kramer P, Themmen AP, Ingraham HA (2001) The serine/threonine transmembrane receptor ALK2 mediates Mullerian inhibiting substance signaling. Mol Endocrinol 15:936-945. CrossRef Medline

Wrana JL, Attisano L, Cárcamo J, Zentella A, Doody J, Laiho M, Wang XF, Massagué J (1992) TGF beta signals through a heteromeric protein kinase receptor complex. Cell 71:1003-1014. CrossRef Medline

Zarbalis K, Siegenthaler JA, Choe Y, May SR, Peterson AS, Pleasure SJ (2007) Cortical dysplasia and skull defects in mice with a Foxcl allele reveal the role of meningeal differentiation in regulating cortical development. Proc Natl Acad Sci USA 104:14002-14007. CrossRef Medline

Zhou CJ, Zhao C, Pleasure SJ (2004) Wnt signaling mutants have decreased dentate granule cell production and radial glial scaffolding abnormalities. J Neurosci 24:121-126. CrossRef Medline

Zhuo L, Theis M, Alvarez-Maya I, Brenner M, Willecke K, Messing A (2001) hGFAP-cre transgenic mice for manipulation of glial and neuronal function in vivo. Genesis 31:85-94. CrossRef Medline

Zouvelou V, Passa O, Segklia K, Tsalavos S, Valenzuela DM, Economides AN, Graf D (2009) Generation and functional characterization of mice with a conditional BMP7 allele. Int J Dev Biol 53:597-603. CrossRef Medline 